\title{
Analisa Karakter Tokoh Andrea Dalam Film The Devil Wears Prada Berdasarkan Pendekatan Humanistik
}

\begin{tabular}{ccc} 
& Sri Mulyati \\
& Universitas Bina Sarana Informatika \\
& & \\
sri.smq@ bsi.ac.id & \\
\hline Diterima & Direvisi & Disetujui \\
$19-01-2020$ & $27-02-2020$ & $28-02-2020$ \\
\hline
\end{tabular}

\begin{abstract}
Abstrack - The writer analyzed a film entitled "The devil Wears Prada". It is an American film drama comedy,2006, which is based on a novel by Lauren Weisberger, 2003, and the same title as the novel. This film tells about a woman editor chief in a big magazine fashion company and how her relationship with her personal assistant. The main actresses in this film are Miranda Priestley as an editor chief in fashion magazine, Runway, and Andrea "Andy"sach, is an ordinary woman who is not fashionable, as a personal asistant of Miranda Priestly. However, in this analysis the writer only focuses on Andrea's character figure, as a personal asistant of the company. This analysis uses qualitative descriptive method that reveals the whole messages of the film and humanistic approach to analyse Andrea's character figure. The result of the analysis shows that Andrea is a simple woman who has no a good sense of style fashion but she a smart and humble woman. Although at the beginning of working Andrea encountered many difficulties which came both from her chief itself or her colleagues, but, in the end, Andrea can adjust to the culture and understand what needs to be done in her office's environtment. So, finally, she got the job she dreamed, that is as a journalist in a big company.
\end{abstract}

\section{Keywords: film, fashion, career women}

Abstrak - Penulis menganalisis sebuah film berjudul "The devil Wears Prada". Ini adalah komedi drama film Amerika, 2006, yang didasarkan pada novel karya Lauren Weisberger, 2003, dan judul yang sama dengan novel tersebut. Film ini bercerita tentang seorang pemimpin redaksi wanita di sebuah perusahaan mode majalah besar dan bagaimana hubungannya dengan asisten pribadinya. Pemain utama dalam film ini adalah Miranda Priestley sebagai kepala editor di majalah fashion, Runway, dan Andrea "Andy" sach, adalah seorang wanita biasa yang tidak modis, sebagai asisten pribadi Miranda Priestly. Namun, dalam analisis ini penulis hanya fokus pada karakter tokoh Andrea, sebagai asisten pribadi perusahaan tersebut. Analisis ini menggunakan metode deskriptif kualitatif yang mengungkapkan seluruh pesan dalam film dan pendekatan humanistik untuk menganalisis tokoh karakter Andrea. Hasil analisis menunjukkan bahwa Andrea adalah wanita sederhana yang tidak memiliki selera gaya busana yang baik tetapi dia wanita yang cerdas dan rendah hati. Meskipun pada awal bekerja Andrea menghadapi banyak kesulitan yang datang baik dari pimpinannya sendiri atau rekanrekannya, tetapi, pada akhirnya, Andrea dapat menyesuaikan diri dengan budaya dan memahami apa yang perlu dilakukan di lingkungan kantornya. Jadi, akhirnya, ia mendapatkan pekerjaan yang ia impikan, yaitu sebagai jurnalis di sebuah perusahaan besar.

\section{Kata kunci: film, mode, wanita karir}

\section{PENDAHULUAN}

Karya sastra adalah suatu media yang digunakan oleh pengarang untuk menyampaikan ide, pemikiran, saran, dan pengalaman pengarang yang disampaikan kepada pembaca.

Karya sastra merupakan ungkapan ide, saran, pengalaman dan pendapat, serta perasaan pengarang dalam bentuk yang imajinatif. Karya sastra berupa cerminan kenyataan yang dikemas secara estetis melalui media bahasa yang di sampaikan dengan cara komunikatif untuk menyampaikan maksud penulis dengan tujuan memberikan nilai keindahan kepada pembaca atau penonton.
Hubungan antara pembaca dan pengarang, karya sastra memiliki peran yang berbeda. Selain berperan sebagai proses transfer informasi dari pengarang ke pembaca, karya sastra juga berperan sebagai teks yang diciptakan oleh pengarang sebagai teks yang diresapi oleh pembaca.

Jenis karya sastra diantaranya adalah; prosa, novel, novela, dongeng, drama, puisi, lirik, dan film. Berikut beberapa pendapat mengenai karya sastra.

Menurut Sumardjo \& Saini (1997: 3) berpendapat bahwa Sastra adalah ungkapan pribadi manusia yang berupa pengalaman, pemikiran, perasaan, ide, semangat, keyakinan dalam suatu 
bentuk gambaran konkret yang membangkitkan pesona dengan alat bahasa.

Berdasarkan definisi di atas dapat disimpulkan bahwa karya sastra adalah ungkapan isi hati atau pikiran pengarang tentang fakta dalam hidupnya yang disajikan dalam bentuk ciptaan yang menarik perhatian pembaca dan atau penonton.

Menurut Mursal Esten (Esten, 1978: 9) berpendapat bahwa Sastra adalah pengungkapan dari fakta artistik dan imajinatif sebagai manifestasi kehidupan manusia dan masyarakat umumnya, melalui bahasa sebagai medium dan memiliki efek positif terhadap kehidupan manusia.

Berdasarkan definisi di atas dapat disimpulkan bahwa karya sastra adalah ungkapan isi hati atau pikiran pengarang yang berupa fakta hidupnya dan atau karangan pengarang tetapi mengandung nilai positif bagi pembaca.

Menurut Terry Eagleton, Sastra merupakan karya tulisan indah (belle letters) yang mencatatkan sesuatu dalam bentuk bahasa yang dipadatkan, didalamkan, dibelitkan, dipanjangpendekan dan diputarbalikan, dijadikan ganjil atau cara penggubahan estetis lainnya melalui alat bahasa (Eagleton, 2010: 4).

Berdasarkan definisi di atas dapat disimpulkan bahwa karya sastra adalah suatu ciptaan berbentuk tulisan yang isinya menarik perhatian pembaca yang isinya diolah sedemikian rupa supaya menarik perhatian pembaca.

Kemudian, menurut Atar Semi, karya sastra adalah suatu bentuk dan hasil pekerjaan seni kreatif yang objeknya (atau subjeknya) adalah manusia dan kehidupannya dengan menggunakan bahasa sebagai medium (1988: 8 ).

Berdasarkan definisi di atas dapat disimpulkan bahwa karya sastra adalah suatu media yang diciptakan berdasar pemikiran kreatif pengarang dengan objek mnusia dan menggunakan bahasa.

Serta menurut Panuti Sudjiman, Sastra merupakan karya lisan atau tulisan yang memiliki berbagai ciri keunggulan seperti keorisinalan, keartistikan, keindahan dalam isi dan ungkapanya (1990 : 68).

Berdasarkan definisi di atas dapat disimpulkan bahwa karya sastra adalah suatu cipataan dalm bentuk lisan atau tulisan yang masinmasing memiliki berbagai daya tarik berupa keindahan penyusunan dan isinya.

Di sisi lain, Novel merupakan karya sastra yang berbentuk tulisan yang menceritakan pengalaman kehidupan seseorang atau beberapa orang tokoh dan diceritakan dengan gaya pengarang, serta menonjolkan karakter dari setiap tokoh novel tersebut. Tujuannya adalah untuk menghibur dan memberikan nilai-nilai positif kehidupan bagi pembaca.

Menurut Nurgiyanto, Novel merupakan bentuk karya fiksi yang dibangun oleh unsur-unsur pembangun. Yakni unsur intrinsic dan ekstrinsik. ( Nurgianto, 2010:10).

Berdasarkan definisi di atas maka dapat disimpulkan bahwa novel adalah bentuk karya berdasarkan pengalaman yang tidak nyata yang memiliki unsur intrinsik dan ekstrinsik.

Pendapat menurut Tarigan, Novel atau sering disebut dengan roman adalah suatu cerita prosa yang fiktif dalam panjang yang tertentu yang melukiskan para tokoh, gerak serta dengan nyata yang representative dalam suatu alur atau suatu keadaan yang agak kacau atau agak kusut. Novel mempunyai ciri bergantung pada tokoh, menyajikan lebih dari satu impresi, lebih dari satu efek, dan lebih dari satu emosi. (Tarigan, 1991:164-165).

Berdasarkan pendapat di atas, maka dapat disimpulkan bahwa novel adalah suatu karya yang berbentuk tulisan panjang berisi tentang kisah yang tidak nyata dengan alur cerita yang tidak beraturan dan memiliki kesan dari suatu kejadian atau luapan emosioanl pengarang.

Menurut Nurgiantoro, Novel merupakan jenis dari genre prosa dalam karya sastra. Prosa dalam pengertian kesusastraan juga disebut sebagai fiksi. Karya fiksi menyaran pada suatu karya sastra yang menceritakan sesuatu yang bersifat rekaan, khayalan, sesuatu yang tidak adadan terjadi sungguh-sungguh sehingga tidak perlu dicari kebenaran pada dunia nyata. (Nurgiantoro, 1991:2).

Berdasarkan definisi di atas novel adalah karya jenis prosa fiksi yang menyajikn cerita yang tidak nyata atau khayalan si pengarang.

Berikutnya adalah karya sastra bentuk film. Menurut Effendy, Film adalah salah satu bentuk karya sastra yang digunakan sebagai media komunikasi yang bersifat media audio visual untuk menyampaikan suatu pesan kepada sekelompok orang yang berkumpul di suatu tempt tertentu. (Effendy,1986,134).

Berdasarkan definisi di atas dapat disimpulkan bahwa film adalah karya yang berbetuk gambar bersuara untuk menyampaikan suatu pesan si pengarang kepada sekelompok orang 
yang berkumpul di suatu tempt tertentu.

Menurut Lev Kuleslov, film adalah melakukan eksperimen dengan mengedit rekaman bersama-sama dengan cara yang berbeda untuk menetukan dampak pada penonton. Hal itu menunjukkan bahwa penonton menjadi penentu hubungan dari bidikan satu ke bidikan yang lainnya. (Lev Kuleshov, 1899).

Berdasarkan definisi di atas maka dapat disimpulkan bahwa film adalah hasil eksperimen dengan cara yang berbeda untuk mendapatkan daya tarik penonton. Penonton merupakan penentu hasil karya yang diciptakan. Makin banyak penonton, maka makin bagus kualitas karya tersebut.

Kemudian menurut Sergei Eisenstein, Potensi tertinggi pada dalam pengeditan terletak pada tabrakan gambar yang berbeda untuk menghasilkan ide-ide baru. (Sergei Eisenstein, 1918).

Berdasarkan definisi di atas dapat disimpulakn bahwa film adalah sekumpulan gambar bersuara yang berbeda dan berurutan yang berisi ide-ide baru dari si pengarang.

Objek penelitian ini adalah film adaptasi, yaitu film The Devil Wears Prada. Dalam film ini penulis fokus pada karakter tokoh Andrea, asisten pribadi pimpinan editor majalah fashion, Runway, Miranda Priestly.

Fungsi dari penelitian ini adalah penulis ingin menambah pengetahuan terkait dunia sastra terutama karya transformasi dari bentuk novel menjadi bentuk film, serta menjadikannya sebagai sumber ilmu pengetahuan tambahan bagi pembaca terutama di bidang karya sastra berbentuk film.

\section{METODOLOGI PENELITIAN}

\section{Pendekatan Penelitian}

Dalam melakukan penelitian penulis menggunakan metode kualitatif deskriptif. metode ini memberikan gambaran dan menyediakan anggapan/dugaan sementara dan prosedur yang digunakan secara detail. Metode kualitatif adalah metode penelitian yang tidak menggunakan data statistik.

"Metode qualitatif adalah metode ilmu manusia dan sosial yang menawarkan beberapa tradisi. Tradisi-tradisi ini mungkin jenis metode untuk mengumpulkan data analisa, dan laporan tertulis, atau keseluruhan rancangan yang termasuk semua fase dalam proses penelitian". (Creswell, 1944)
Berdasarkan definisi di atas dapat disimpulakan bahwa metode qualitatif adalah pandangan manusia melalui pengamatan agar mendapatkan fakta setelah pengamatan, kemudian dilakukan pengumpulan laporan data, dan melakukan analisa data.

\section{Analisis Data}

Dalam dunia sastra ada beberapa pendekatan sastra yang digunakan untuk menganalisa karya-karya sastra tersebut. Diantaranya adalah pendekatan sosiologi dan psikologi sastra.

Dari kedua pendekatan tersebut dibagi ke dalam beberapa fase pendekatan di antaranya pendekatan psikologi humanistik atau dikenal juga sebagai pendekatan kemanusiaan atau kepribadian (manusia).

Dalam penelitian ini penulis menggunakan pendekatan humanistik. Pendekatan humanistik adalah pendekatan yang multifase terhadap pengalaman dan tingkah laku manusia yang memusatkan perhatian pada keunikan dan aktualisasi diri manusia. Pendekatan humanistik merupakan kajian yang memandang karya sastra sebagai aktifitas kejiwaan. Artinya karya sastra tidak lepas dari kehidupan yang menggambarkan berbagai rangkaian kepribadian manusia.

Tujuan dari penggunaan pendekatan ini adalah untuk memberikan sebuah gambaran dari kondisi dalam sebuah situasi secara sistematis, akurat, dan aktual, sehingga akan mempermudah memahami isi dari gambaran setiap karakter terutama karakter tokoh Andrea dalam film The Devil Wears Prada.

\section{HASIL DAN PEMBAHASAN}

\section{Adaptasi karya sastra}

Adaptasi karya sastra adalah sebagai suatu proses "penerjemahan" suatu karya sastra ke dalam media yang berbeda, contohnya dari novel menjadi drama atau film. Akan tetapi, tak menutup kemungkinan bahwa adaptasi juga dapat dilakukan ke dalam media yang sama, seperti dari novel ke novel.

Di negri ini sudah banyak film hasil adaptasi dari novel, di antaranya adalah : Antologi Rasa, Dilan 1991, Bumi Manusia, Wedding Agreement, dan Twivortiare.

\section{Ekranisasi}

Transformasi karya sastra ke dalam bentuk film disebut ekranisasi. Istilah ini berasal dari bahasa 
Prancis, ecran, yang berarti layar. Selain ekranisasi yang menyatakan proses transformasi dari karya sastra ke film disebut filmisasi.

Eneste menyebutkan bahwa sebuah ekranisasi adalah suatu proses pelayarputihan atau pemindahan atau pengangkatan sebuah novel ke dalam film. (Eneste, 1991).

Berdasarkan definisi di atas dapat disimpulkan bahwa ekranisasi adalah proses pemindahan atau pengalihan wahana dari bentuk novel kedalam bentuk film. Dengan kata lain, ekranisasi adalah bentuk pengadaptasian karya sastra tulis ke dalam bentuk gambar bersuara..

Selanjutnya, menurut Nurgiyantoro mengemukakan, transformasi adalah perubahan suatu hal atau keadaan. Bentuk perubahan, ada kalanya berubah kata, kalimat, struktur, dan isi karya sastra (novel) itu sendiri. Selain itu transformasi juga bisa dikatakan, pemindahan atau pertukaran suatu bentuk ke bentuk lain, yang dapat menghilangkan, memindahkan, menambah, atau mengganti unsur seperti transformasi novel ke film. (Nurgiyantoro, 2007:18)

Bermacam-macam alasan mendasari proses transformasi dari novel ke film. Alasan-alasan tersebut antara lain karena sebuah novel sudah terkenal, sehingga masyarakat pada umumnya sudah tak asing lagi dengan cerita novel itu. Pada akhirnya, ketidakasingan tersebut mendukung aspek komersil. Alasan terakhir adalah karena ide cerita novel dianggap bagus oleh masyarakat dan penulis skenario film. Munculnya fenomena pengadaptasian novel ke bentuk film merupakan perubahan substansi dari wacana yang memunculkan istilah ekranisasi.

Ekranisasi disebut juga sebai alih wahana. Menurut Damono, Alih wahana adalah perubahan dari satu jenis kesenian ke jenis kesenian lain. Karya sastra tidak hanya bisa diterjemahkan yakni dialihkan dari satu bahasa ke bahasa lain, tetapi juga dialihwahanakan, yakni diubah menjadi jenis kesenian lain. Kegiatan di bidang ini akan menyadarkan kita bahwa sastra dapat bergerak kesana kemari, berubahubah unsur-unsurnya agar bisa sesuai dengan wahananya yang baru (Damono, 2005:96).

Dengan kata lain, alih wahana adalah pemindahan media dari media tulis berupa novel ke dalam media gambar bersuara yang berbeda-beda.

Sebagian besar karya film merupakan bentuk adaptasi dari sebuah novel. Film dianggap sebagai media komunikasi yang ampuh terhadap masyarakat yang menjadi sasarannya, karena sifatnya yang audio visual, yaitu gambar dan suara yang hidup. Film mampu bercerita banyak dalam waktu singkat. Ketika menonton film, penonton seakanakan dapat menembus ruang dan waktu. Film bahkan dapat mempengaruhi penonton.

Pesan film pada komunikasi massa dapat berbentuk apa saja tergantung dari misi film tersebut. Tetapi umumnya sebuah film dapat mencakup berbagai pesan, baik itu pesan pendidikan, hiburan dan atau informasi. Pesan dalam film adalah menggunakan mekanisme lambang-lambang (gambar) yang ada pada pikiran manusia berupa pesan, suara, perkataan, dan percakapan.

Film "The Devil Wears Prada" adalah salah satu hasil proses adaptasi karya sastra novel menjadi bentuk film. Film ini adalah film drama komedi Amerika tahun 2006, yang dibuat berdasarkan novel Lauren Weisberger tahun 2003, dengan nama yang sama. Film ini menceritakan tentang sosok pemimpin wanita sebuah perusahaan majalah fashion mode terkemuka di Paris dan bagaimana hubungannya dengan salah satu asisten pribadinya, Andrea, serta menggambarkan perjuangan hidupnya.

\section{Pendekatan Humanistik}

Humanistik adalah pendekatan yang multifase terhadap pengalaman dan tingkah laku manusia yang memusatkan perhatian pada keunikan dan aktualisasi diri manusia. Pendekatan humanistik merupakan kajian yang memandang karya sastra sebagai aktifitas kejiwaan. Artinya karya sastra tidak lepas dari kehidupan yang menggambarkan berbagai rangkaian kepribadian manusia.

Menurut Koeswara, Manusia menurut eksistensialisme adalah hal yang mengada-dalam dunia (being-in-the-world), dan menyadari penuh akan keberadaannya (Koeswara, 2001 : 113).

Berdasarkan teori di atas dapat disimpulkan bahwa manusia adalah makhluk yang menyadari keberadaannya di dunia ini. Manuisa memahami apa yang harus dilakukan dalam hidup ini sebagai bagian dari perjuangannya untuk melalui hidup.

Menurut Arthur W. Combs menjelaskan bagaimana persepsi dalam memandang tingkah laku. Untuk mengerti tingkah laku manusia, yang penting adalah mengerti bagaimana dunia ini dilihat dari sudut pandangnya.( Arthur Combs 1912-1999).

Dari pernyataan tersebut dapat disimpulkan bahwa salah satu dari pandangan humanistik mengenai perasaan, persepsi, kepercayaan, dan tujuan tingkah laku da ri dalam yang membuat orang berbeda dengan orang lain. Untuk mengerti orang lain, yang penting adalah melihat dunia sebagai yang dia lihat, dan untuk menentukan 
bagaimana orang berpikir, merasa tentang dia atau tentang dunianya.

Perilaku manusia seperti perasaan, persepsi, keyakinan, dan maksud, menyebabkan seseorang berbeda dengan orang lain. Untuk memahami orang lain, kita harus melihat dunia orang lain seperti ia merasa dan berpikir tentang dirinya.

Menurut Abraham H. Maslow (1908-1970), menyatakan manusia adalah suatu ketunggalan yang mengalami, menghayati, dan pada dasarnya aktif, punya tujuan serta punya harga diri. Selain itu manusia juga harus di pandang dengan penghargaan yang tinggi terhadap harga dirinya, perkembangan pribadinya, perbedaan individualnya dan dari sudut pandang kemanusiaan nya itu sendiri. (Abraham $\mathrm{H}$. Maslow 1908-1970).

Dari teori pendekatan tersebut dapat disimpulkan bahwa manusia mempunyai nalurinaluri dasar yang menjadi nyata sebagai kebutuhan. kebutuhan tersebut adalah: kebutuhan fisik/biologis, kebutuhan akan rasa aman, kebutuhan akan rasa dimiliki dan cinta, kebutuhan akan penghagaan dan hargadiri, kebutuhan aktualisasi atau perwujudan diri, serta kebutuhan estetik.

Berikutnya pendekatan menurut Carl Roger ; Pendekatan humanistik didasarkan pada suatu "daya hidup" yang disebut kecenderungan aktualisasi. Kecenderungan aktualisasi tersebut diartikan sebagai motivasi yang menyatu dalam setiap diri makhluk hidup dan bertujuan mengembangkan seluruh potensinya semaksimal mungkin.(Carl Roger,1902 1987).

Berdasar teori tersebut dapat disimpulkan bahwa makhluk hidup bukan hanya bertujuan bertahan hidup saja, tetapi ingin memperoleh apa yang terbaik bagi keberadaannya dan mengembangkan semua potensi dan kemampuan yang ada pada diri makhluk hidup tersebut.

Di sisi lain, Humanisme adalah sebuah pemikiran filsafat yang mengedepankan nilai dan kedudukan manusia serta menjadikannya sebagai kriteria dalam segala hal.

Pendekatan humanistik dapat dimengerti dari tiga ciri utama, yaitu :

a. Pendekatan humanistik menawarkan satu nilai yang baru sebagai pendekatan untuk memahami sifat dan keadaan manusia.

b. Pendekatan humanistik menawarkan pengetahuan yang luas akan kaidah penyelidikan dalam bidang tingkah laku manusia. c. Pendekatan humanistik menawarkan metode yang lebih luas akan kaidah-kaidah yang lebih efektif.

\section{Penemuan Data}

Pada bagian ini penulis menjelaskan penemuan data menggunakan tabel yang menggambarkaan hasil analisa karakter Andrea, dari fase pertamakali ia memulai kerja sampai akhir fase di Runway, Paris.

Hidup adalah perjuangan dan bekerja adalah salah satu bentuk perjuangan itu. Tetapi terkadang pekerjaan yang sudah didapatkan tidak sesuai dengan yang diharapkan. Banyak ketidakcocokkan antara kualifikasi dengan deskripsi tugas kerja, dan atau mungkin masalah tidak cocok dengan budaya organisasi di tempat kerja. Selain itu, seringkali terjadi kasus tentang senior yang sepertinya selalu membenci yunior setiap hari. Kondisi seperti ini yang paling sering membuat karyawan mudah berkecil hati terutama karyawan baru, bahkan dapat menurunkan prestasi kerja karyawan tersebut.

Setiap organisasi atau perusahaan harus memiliki seorang pemimpin dan memiliki satu atau lebih asisten pribadi. Pemimpin adalah wakil pengusaha dan berkuasa dalam segala hal yang berkenaan dengan pengelolaan perusahaan yang dipimpinnya. Pimpinan bertanggungjawab penuh atas maju mundurnya perusahaan. Pemimpin merupakan salah satu komponen penting sebuah perusahaan.

Keberadaan seorang pemimpin penting karena untuk mengkoordinir jalannnya suatu organisasi atau perusahaan, berdasarkan visi misi yang telah ditetapkan. Dan kemampun dalam memimpin merupakan syarat penting yang haus dimiliki tiap pimpinan.

Kesuksesan sebuah organisasi sangat ditentukan oleh pimpinan dalam memimpin perusahaan atau organisasinya. Ibarat kapal layar,seorang pemimpin adalah nahkoda kapal yang akan membawa kemana kapalnya hendak berlayar, ia harus bisa menjadi pengontrol dalam perusahaan atau organisasi. Seorang pemimpin harus mampu mengarahkan dan bersikap tegas pada bawahannya dalam memimpin dan memberikan contoh panutan yang baik supaya arah tujuan majunya perusahaan atau organisasi,yang akan dicapai jelas terkoordinir dan sukses tercapai.

Namun terkadang ada pimpinan sebuah organisasi atau perusahaan yang memiliki sifat sinis, dan sadis kepada bawahannya. Memberikan tugastugas kerja yang tidak masuk akal, tidak sesuai dengan kewajiban kerja yang semestinya, serta emberikan instruksi pada bawahannya dengan 
kalimat bernada marah. Hal seperti ini sering dialami oleh sekertaris atau asisten pribadi pimpinan.

Kondisi inilah yang menjadi cerita pada film berjudul The Devil Wears Prada. Hal yang dialami oleh Andrea, asisten pribadi Miranda Priestley. Latar belakang cerita tentang perubahan kehidupan seorang perempuan bernama Andrea Sachs yang merupakan jurnalis lulusan Northwestern University. Ia memiliki mimpi untuk bekerja di perusahaan publikasi New York City. Namun akhirnya memutuskan untuk mengambil kesempatan sebagai asisten pribadi Miranda Priestly, seorang pemimpin redaksi majalah busana "Runway" yang terkenal sadis namun sangat berdedikasi untuk pekerjaannya.

Asisten pribadi seorang pimpinan perusahaan atau organisasi yang pada umumnya disebut sebagai sekertaris juga sangat penting keberadaannya. Tetapi satu hal yang harus selalu diingat oleh para pimpinan perusahaan atau organisasi, yaitu bahwa asisten juga hanya manusia biasa. Jadi tugas-tugas kerja yang dilimpahkan pada asisten juga harus sesuai dengan deskripsi pekerjaannya. Dihargai oleh pimpinannya juga sudah sewajarnya diterima oleh asisten tersebut.

Pada dasarnya tugas asisten pimpinan umumnya adalah membuat jadwal pertemuan pertemuan atau penerbangan pimpinannya dan membuat laporan - laporan kerja. Keberhasilan seorang pemimpin sangat membutuhkan bantuan seorang atau lebih asisten. Pemimpin tidak mungkin mengatur semua urusan kerjanya hanya oleh dirinya sendiri.

Asisten pribadi pimpinan harus mampu menyesuaikan diri dengan tugas-tugas kerjanya. Asisten pribadi harus mampu berpikir dan bergerak cepat dan tepat. Karena begitu banyak tugas kerja yang harus diselesaikan oleh asisten tepat pada waktunya. Apalagi perusahaan atau organisasi tempat berkerja adalah sebuah perusahaan atau organisasi yang besar dan terkemuka.

Berlatar belakang pendidikan jurnalis dan tidak memiliki selera fashion baik seperti yang menjadi standar bekerja di Runway, Andrea awalnya sempat diremehkan, baik oleh Miranda, si pimpinan, dan asisten utamanya, Emily Charlton, serta Nigel, perancang busana di kantor itu.

Gaya berpakaiannya yang berbeda seratus delapan puluh derajat dengan semua pegawai di Runway membuat rekan-rekan kerjanya heran. Karena mereka tahu posisi Andrea adalah sebagai asisten pemimpin redaksi majalah fashion terkemuka di Paris. Meskipun begitu, ia adalah pribadi yang cerdas dan Miranda mampu melihat sisi lain dari Andrea, yang kemudian membuatnya berubah pikiran untuk mempekerjakan Andrea.
Kemudian Andrea menemui Nigel untuk meminta saran atas apa yang dialaminya. Dengan saran dari Nigel, Andrea berhasil merubah penampilannya menjadi lebih modis, menarik dan disukai oleh Miranda dan teman-temannya terutama Emily yang selalu memandang sinis penampilannya.

Selanjutnya, karakter tokoh-tokoh dalam film The Devil Wears Prada dideskripsikan sebagai berikut:

Andrea, adalah wanita sederhana yang penuh semangat, pandai bergaul, cerdas dan ramah. Memiliki keyakinan diri yang tinggi, selalu berfikir positif, baik terhadap atasan, rekan kerja dan bahkan pekerjaannya yang sering tidak wajar dan tidak sesuai dengan posisi jabatannya sebagai asisten pribadi Miranda.

Miranda, adalah seorang pemimpin yang otoriter, ambisius, sangat menekankan orientasi pada tugas-tugas kerja tanpa memperhatikan kebahagiaan karyawannya. Baginya karyawan hanyalah alat untuk mencapai tujuannya. serta ia akan melakukan segala cara demi meningkatkan reputasi Prada di mata dunia. Sering menghina bawahannya secara langsung dan selalu menunjukkan powernya tanpa mentolelir sedikitpun kesalahan yang dilakukan bawahannya. Namun di balik sikapnya yang otoriter, ia memiliki dedikasi yang tinggi pada tugas pekerjaannya.

Emily, adalah karyawan yang sangat berambisi dalam menggapai mimpinya dengan pergi ke Paris dan mendapatkan pekerjaan di Runway. Baginya pekerjaan adalah sarana untuk selalu tampil modis dan trendi. Ia akan sangat terlihat disiplin jika ada Miranda, sehingga dalam melakukan perkerjaan cenderung terlihat tegang. Ia juga karyawan yang cerdas dan cukup optimis dalam berpikir.

Nigel, adalah penasehat Miranda di bidang fashion. Ia pandai menyesuaikan diri dengan keadaan, memiliki standar kerja, serta cukup mampu memberikan masukan terhadap rekan kerja yang berkeluh kesah dan memiliki semangat yang tinggi. Namun di balik semua itu, Ia juga sering merasa lelah dengan gaya kepemimpinan Miranda, sehingga selalu berkeinginan bahwa suatu hari nanti ia akan lebih baik dari Miranda.

Manusia adalah makhluk yang baik dan dapat dipercaya, yaitu makhluk yang berupaya menjalin hubungan yang bermakna dan konstruktif dengan orang lain. Manusia lebih bijak dari pikiranpikiran yang disadarinya. Manusia adalah makhluk yang mengalami, yang memikirkan, yang berkehendak, yang merasakan dan yang mempertanyakan.

Kehidupan ada pada saat ini, yaitu lebih dari sekedar tingkah laku yang ditentukan oleh peristiwa 
masa lalu, tetapi nilai kehidupan terletak pada saat sekarang, bukan pada masa lalu atau pada saat yang akan datang.

Gaya kepemimpinan Miranda yang otoriter dan sombong, mengakibatkan rasa takut bawahannya setiap saat ada Miranda di kantor. Selain karena tampang wajahnya yang sinis, juga ia selalu memberikan tugas-tugas kerja semaunya sendiri tanpa mempertimbangkan perasaan bawahannya. Semua kemauannya harus dikerjakan tanpa kompromi meskipun ada banyak tugas kerja yang tidak sesuai. Meskipun suasana kerja di Runway seperti itu, Andrea selalu berpikir positif dan menuruti semua perintah Miranda.

Namun manusia lebih bijak dari pikiranpikiran yang disadarinya. Manusia adalah makhluk yang mengalami, memikirkan, berkehendak, merasakan dan yang mempertanyakan. Kehidupan ada pada saat ini, yaitu lebih dari sekedar tingkah laku yang ditentukan oleh peristiwa masa lalu, dan nilai kehidupan terletak pada saat sekarang, bukan pada masa lalu atau pada saat yang akan datang.

Manusia adalah makhluk yang bersifat subyektif, tingkah laku manusia hanya dapat dipahami berdasarkan dunia subyektifnya, yaitu bagaimana individu itu memandang diri dan lingkungannya. Hubungan manusiawi yang mendalam merupakan salah satu kebutuhan pokok manusia, meningkatkan hubungan antar pribadi yang mendalam memiliki potensi yang sangat besar sebagai sumber kesejahteraan mental manusia.

Manusia memiliki kecenderungan kearah aktualisasi, yaitu kecenderungan untuk bergerak ke arah pertumbuhan, kesehatan, penyesuaian, sosialisasi, realisasi diri, kebebasan dan otonomi.

Awalnya Andrea merasa tidak peduli dipandang sebelah mata oleh karyawan lainnya yang berkomentar bahwa Miranda salah mempekerjakan orang untuk menjadi asistannya, karena dia merasa nyaman dengan penampilannya yang seadanya dan sama sekali tidak berminat untuk mengubah penampilannya. Namun dia terus-menerus mendapat tekanan baik oleh karyawan lain maupun dari Miranda sendiri, yang akhirnya membuat dia ingin keluar dari pekerjaan tersebut.

Tetapi naluri Andrea sebagai manusia yang ingin diakui keberadaannya muncul. Menghadapai perlakuan-perlakuan yang tidak menyenangkan, membuat Andrea berpikir untuk segera melakukan perubahan pada dirinya. Ia menyadari bahwa kedisiplinan kerja saja tidak cukup bagi seorang asisten pimpinannya. Tetapi ia juga harus mengikuti budaya kerja di Runway, yaitu dengan berpakaian modis.
Kekecewaan Andrea atas sikap Miranda diceritakan pada Nigel, penasehat fashion di Prada. Nigel menaggapi bahwa sikap Andrea berlebihan. Nigel mengatakan bahwa untuk bekerja di Prada harus memiliki mental yang lebih tangguh lagi. Sikap Nigel membuat Andrea jadi kembali bersemangat. Lalu ia meminta Nigel untuk memperbaiki cara berbusananya dengan harapan Miranda bisa menyukainya. Nigel dengan senang hati membantu Andrea. Ia memberikan beberapa pasang baju dan sepatu koleksi Prada.

Setelah beberapa waktu berusaha mengamati, menjalani, dan memahami budaya kerja di Runway, Kemudian ia berniat melakukan perubahan pada dirinya sesuai budaya kerja di tempat ia bekerja. Penampilan Andrea yang mendadak menjadi modis, cukup membuat Miranda terkesima dan pandangannya mengembalikan kepercayaan diri Andrea.

Hari demi hari, Andrea semakin sempurna dalam melaksanakan tugas-tugasnya kerjanya. Ambisinya untuk menjadi seorang jurnalis selalu menjadi semangat utuk bekerja sebaik mungkin. Dengan harapan setelah satu tahun ia akan diterima dimana saja. Sampai pada akhirnya Andrea menyadarai bahwa ambisinya itu membuatnya kehilangan teman-temannya, kekasih dan bahkan waktu bersama keluarganya. Idealismenya yang tidak mau disamakan dengan karakter Miranda, membuatnya tanpa berpikir panjang lagi untuk mengundurkan diri dari Prada. Ia tidak ingin kesibukan kerjanya berpengaruh pada hubungannya dengan orang-orang yang dicintainya di sekitarnya di kemudian hari. Ia juga ingin mewujudkan citacitanya sebagai jurnalis. Andrea.

Berikut tabel yang menggambarkan karakter

Tabel 1. Gambaran Karakter Andrea

\begin{tabular}{|l|l|l|l|l|}
\hline \multicolumn{5}{|c|}{ Gambaran karakter Andrea } \\
\hline $\begin{array}{l}\text { Keprib } \\
\text { adian }\end{array}$ & $\begin{array}{l}\text { Cara } \\
\text { berpiki } \\
\text { r }\end{array}$ & Feeling & $\begin{array}{l}\text { Penga } \\
\text { matan }\end{array}$ & $\begin{array}{l}\text { nindaka } \\
\text { berdasar } \\
\text { pengala } \\
\text { man }\end{array}$ \\
\hline $\begin{array}{l}\text { Sederh } \\
\text { ana \& } \\
\text { rendah } \\
\text { hati }\end{array}$ & $\begin{array}{l}\text { Berpiki } \\
\text { positive }\end{array}$ & $\begin{array}{l}\text { respons } \\
\text { ive }\end{array}$ & Teliti & $\begin{array}{l}\text { Menyeles } \\
\text { aikan } \\
\text { tugas } \\
\text { kerja } \\
\text { dengan } \\
\text { sempurna }\end{array}$ \\
\hline $\begin{array}{l}\text { Sopan } \\
\text { Percaya } \\
\text { diri }\end{array}$ & $\begin{array}{l}\text { Pengert } \\
\text { ian }\end{array}$ & Cermat & $\begin{array}{l}\text { Penampil } \\
\text { an } \\
\text { menjadi } \\
\text { fashionab } \\
\text { le }\end{array}$ \\
\hline
\end{tabular}




\begin{tabular}{|l|l|l|l|l|}
\hline Supel & $\begin{array}{l}\text { Penuh } \\
\text { keyakin } \\
\text { an }\end{array}$ & $\begin{array}{l}\text { Cepat } \\
\text { tangga } \\
\text { p }\end{array}$ & Cepat & $\begin{array}{l}\text { Lebih } \\
\text { berseman } \\
\text { gat }\end{array}$ \\
\hline Cerdas & $\begin{array}{l}\text { Penuh } \\
\text { tanggun } \\
\text { gjawab }\end{array}$ & $\begin{array}{l}\text { Berded } \\
\text { ikasi } \\
\text { pada } \\
\text { pekerja } \\
\text { an }\end{array}$ & Tepat & Berani \\
\hline
\end{tabular}

\section{KESIMPULAN DAN SARAN}

\section{Kesimpulan}

Pada bagian ini penulis menyimpulkan atas hasil penelitian karakter tokoh Andrea dalam film The Devil wears Prada; pertama, karakter tokoh Andrea adalah sosok seorang wanita muda yang sederhana, lugu, dan rendah hati, namun cerdas. Kedua, Andrea menyadari bahwa perubahan baik pada dirinya harus dilakukan. Ketiga, Andrea adalah sosok yang berani dan percaya diri untuk melakukan perubahan.

Terakhir, film The Devil Wears Prada menyampaikan pesan moral, yaitu pesan supaya menjaga kedisiplinan kerja, mengikuti budaya kerja setempat, menjaga etika, dan meningkatkan prestasi kerja di mana pun.

\section{Saran}

Untuk menambah pemahaman pembaca dalam dunia sastra khususnya film, pembaca harus menonton film secara keseluruhan, supaya dapat memahami pesan yang disampaikan oleh pengarang dalam film tersebut.

\section{REFERENSI}

Ardianto, D. T. (2016) 'Teori Adaptasi Sebuah Pendekatan dalam Penciptaan Film', Mudra Journal of Art and Culture, pp. 150-157.

Covey, S. R. (1989) 'The seven habits of highly effective people. An approach to solving personal and professional problems'. Available at: http://www.ronaldsoh.com/wpcontent/uploads/2015/07/Summaries.com-The-7Habits-Of-Highly-Effective-People.pdf.

'David Kolb, "Hegel versus Heidegger" from' (no date), pp. 1-38.

Francis, N. and Kritsonis, W. A. (2006) 'A Brief Analysis of Abraham Maslow's Original Writing of', Online Submission, 3(1), pp. 1-7.
Gumilar, R. (2009) 'Hubungan antara persepsi terhadap kepemimpinan wanita dengan disiplin kerja'.

Hadipranata, A. F. and Sudardjo, - (1999) 'Pengaruh pembentukan kelompok (team building) terhadap etos kerja dan kontribusinya bagi produktivitas kerja insani', Jurnal Psikologi, 26(1), pp. 18-28. doi: 10.22146/JPSI.6996.

Hutchison, C. (no date) 'Adapting Novel into Film', pp. 1-18.

In, F. and Classroom, T. H. E. (2011) 'Adaptation From Novel To Film', pp. 15-21.

Iversi, U. N. and Press, C. (1961) 'FILM'.

Johnston, J. H., Driskell, J. E. and Salas, E. (1997) 'Vigilant and hypervigilant decision making', Journal of Applied Psychology, 82(4), pp. 614-622. doi: 10.1037/0021-9010.82.4.614.

Lindsay Holmes, F. (1920) 'Being and Becomming', pp. 1-128.

Marciniak, M. (2003) 'The Appeal of Literature-tofilm adaptations', Lingua ac Communitas, (17), pp. 149-171.

Marcus, L. (2005) 'Literature and cinema', The Cambridge History of Twentieth-Century English Literature, 3(1), pp. 335-358. doi: 10.1017/CHOL9780521820776.021.

Muh. Hizbul Muflihin (2009) 'Aplikasi Dan Implikasi Teori Behaviorisme Dalam Pembelajaran (Analisis Strategis Inovasi Pembelajaran)', Khazanah Pendidikan, pp. 1-11.

Ratu, B. (2015) 'Psikologi Humanistik (Carl Rogers) Dalam Bimbingan dan Konseling', Kreatif, (1951), pp. 10-18.

Riyadi, S. (2014) 'Penggunaan Film Adaptasi Sebagai Media Pengajaran Sastra', Jurnal Pendidikan Bahasa dan Sastra, 14(2), p. 241. doi: 10.17509/bs_jpbsp.v14i2.722.

Saputra, H. S. P. (2009) 'TRANSFORMASI LINTAS GENRE: DARI NOVEL KE FILM, DARl FILM', Humaniora, 21, pp. 41-45.

Sense, I. F. (no date) 'Ine Film Sense'.

Tambusai, K., Hulu, R. and Up, C. (2010) 'Kata-kata kunci ':, pp. 1-20.

Winataputra, U. S. et al. (2014) 'Teori belajar dan pembelajaran'. 